\title{
PENGARUH PUPUK ORGANIK CAIR NASA TERHADAP PERTUMBUHAN BIBIT TANAMAN JATI PUTIH (Gmelina arborea Roxb)
}

\author{
Josina Hutubessy \\ irenehutubessy91@yahoo.co.id
}

\section{Program Studi Agroteknologi, Fakultas Pertanian, Universitas Flores}

\begin{abstract}
This research aims to determine the effect of concentration of organic fertilizer Super NASA tothe growth of seeds of white teak and to know the optimum dosage of organic fertilizer Super NASA can increase the growth of NASA plant seed white teak.

The design used in this study was a Randomized Block Design with the treatment used is N0: without fertilizer Super NASA NASA, N1: Fertilizer NASA7 $.5 \mathrm{ml}$ seeds $^{-1}$, N2: Fertilizer NASA $15 \mathrm{ml} \mathrm{seeds}^{-1}$, N3: Fertilizer NASA $22.5 \mathrm{ml} \mathrm{seeds}^{-1}$, N4: Fertilizer NASA $30 \mathrm{ml}$ seeds $^{-1}$. Variable observation in this study is height of plant, number of leaf, leaf area, fresh weight $\tan ^{-1}$, fresh and dry weight oven $\tan ^{-1}$.

The results showed that the granting of Fertilizer NASA exerted highly significant effect onheight of plant $(23,65 \%)$, the number of leaf is not significant, leaf area $(53,61 \%)$, fresh weight $\tan ^{-1}(60,89 \%)$ and dry weight $\tan ^{-1}(55,43 \%)$. The optimum dosage of Fertilizers NASA give the seed growth of white teak is best on the seed ${ }^{-1}$ is $30 \mathrm{ml}$.
\end{abstract}

Keywords: fertilizer Super NASA, seed, white teak

\section{PENDAHULUAN}

Jatih Putih (Gmelina arborea

Roxb.) adalah tanaman penghasil kayu

yang produktif dan memiliki nilai jual

yang tinggi. Jati Puth merupakan salah

satu jenis pohon family verbenaceae,

yang sudah dibudidayakan sejak dulu.

Terdapat 30.000 spesies dari jati putih

yang telah diidentifikasi dan 950 spesies di antaranya memiliki fungsi biofarmaka atau disebut juga sebagai tumbuhan obat. Menurut Irwanto (2006), kebutuhan akan kayu jati selalu meningkat,baik dari dalam maupun luar negeri, sedangkan populasi semakin menipis dikarenakan siklus umur panen jati konvesional relatif lama, yakni kurang lebih 45 tahun. 
Josina: Pengaruh pupuk organik cair Nasa terhadap pertumbuhan bibit tanaman Jati Putih (Gmelina arborea Roxb.)

Penggunaan serta pemilihan bibit dan aplikasi pupuk yang tidak sesuai adalah salah satu permasalahan yang sering muncul pada pembibitan tanaman jati putih. Hal ini mengakibatkan pertumbuhan tanaman jati putih tumbuh tidak optimal. Sedangkan permasalahan yang umumnya muncul dalam usaha pengembangan tanaman jati setelah fase pembibitan adalah kegagalan penanaman di lapangan yang salah satunya karena kematian bibit saat pemindahan ke lapangan (Husna dkk, 2007).Untuk mendapatkan bibit yang berkualitas , salah satu cara yang dapat diguanakan adalah adanya penggunaan pupuk yang berkualitas.

$$
\text { Upaya yang dapat dilakukan }
$$

untukmengatasi kegagalan pertumbuhan bibit saat pemindahan di lapangan dengan menggunakan pupuk organik dalam pembudidayaannya. Salah satu pupuk organikyang dapat dimanfaatkan adalah pupuk organik cair NASA. Pupuk organik cair NASA adalah formula khusus untuk tanaman juga peternakan dan perikanan, yang dibuat dari bahan-bahan organik yang bertujuan untuk meningkatkan kuantitas dan kualitas produksi tanaman serta kelestarian lingkungan (Anonimous, 2010).

Kandungan yang terdapat pada pupuk organik cair (NASA) adalah $\mathrm{N}$ $0.12 \%, \mathrm{P} 2 \mathrm{O} 50.03 \%, \mathrm{~K} 0.31 \%, \mathrm{Ca}$ 60.40 ppm, S 0.12\%, Mg 16.88 ppm, Cl $0.29 \%$, Mn 2.46 ppm, Fe 12.89 ppm, Cu < 0.03 ppm, Zn 4.71 ppm, Na $0.15 \%, \mathrm{~B}$ 60.84 ppm, Si $0.01 \%$, Co < 0.05 ppm, Al 6.38 ppm, $\mathrm{NaCl} 0.98 \%$, Se 0.11 ppm, As $0.11 \mathrm{ppm}, \mathrm{Cr}<0.06$ ppm, Mo $<0.2 \mathrm{ppm}$, $\mathrm{V}<0.04 \mathrm{ppm}, \mathrm{SO} 40.35 \%, \mathrm{C} / \mathrm{N}$ ratio $0.86 \%$, ph 7.5, Lemak $0.44 \%$, Protein $0.72 \%$ (Anonimous, 2010).Manfaat pupuk organik cair NASA yaitu menjadikan tanah yang keras berangsurangsur menjadi gembur dan dapat 
Josina: Pengaruh pupuk organik cair Nasa terhadap pertumbuhan bibit tanaman Jati Putih (Gmelina arborea Roxb.)

melarutkan pupuk kimia di dalam tanah sehingga dimanfaatkan tanaman. Kandungan unsur makro dan unsur mikro dalam pupuk organik cair NASAdapat mengurangi penggunaan urea, SP-36 dan $\mathrm{KCl}$ hingga $12,5 \%$ - 25\%. Dalam 1 liter pupuk organik cair NASA memiliki fungsi yang setara dengan 1 ton pupuk kandang. Manfaat lain dari pupuk organik cair NASA yaitu memacu pertumbuhan tanaman dan akar, merangsang pengumbian, pembungaan dan pembuahan serta mengurangi kerontokan bunga dan buah (mengandung hormon atau Zat Pengatur Tumbuh seperti Auksin, Sitokinin dan Giberllin), membantu perkembangan mikroorganisme dan organisme tanah yang bermanfaat bagi tanaman, dan meningkatkan daya tahan tanaman terhadap hama penyakit(Anonimous, 2013).
Berdasarkan hasil penelitian Pranantha (2009), untuk memperoleh pertumbuhan semai pinus yang baik, dapat diberikan Media Tanam Tanah + Pasir dengan perbandingan 1:1dan konsentrasi larutan Pupuk Organik Cair NASA $15 \mathrm{ml} / \mathrm{l}$ air. Pemberian pupuk organik cair NASA dengan konsentrasi tersebut mempercepat pertumbuhan dan perkembanganbibit pinus(Pinus merkusii Jungh et de Vriese). Berdasarkan hal tersebut diatas, maka penulis berkeinginan untuk melakukanpenelitian mengenai "Pengaruh Pemberian Pupuk Organik Cair NASA Terhadap Pertumbuhan Bibit Tanaman Jati Putih (Gmelina arborea Roxb.)“.

\section{METODE PENELITIAN}

\section{Lokasi dan Waktu Penelitian}

Penelitian ini dilaksanakan pada rumah kacakebun percobaan Fakultas Pertanian, Universitas Flores, Kelurahan Lokoboko, Kecamatan Ndona, Kabupaten 
Josina: Pengaruh pupuk organik cair Nasa terhadap pertumbuhan bibit tanaman Jati Putih (Gmelina arborea Roxb.)

Ende. Penelitian ini dilaksanakan pada bulan November 2013 sampai Februari tahun 2014.

\section{Bahan dan Alat}

Bahan yang digunakan dalam

penelitian ini yaitu biji jati putih, pupuk organik cair (NASA), tanah, dan polibag. Alat yang digunakan dalam penelitian ini yaitu cangkul, pisau, gembor, meteran, timbangan, oven, plastik transparan, tali rafiah, bamboo, ayakan, alat-alat tulis, jangka sorong, dan lain-lain.

\section{Rancangan Penelitian}

Rancangan yang digunakan dalam percobaan ini adalah Rancangan Acak Kelompok (RAK) dengan pola faktor tunggal yang terdiri dari lima perlakuan pupuk organik cair NASA, yaitu $\mathrm{N}_{0}: 0 \mathrm{ml}$ bibit $^{-1}, \mathrm{~N}_{1}: 7,5 \mathrm{ml} \mathrm{bibit}^{-1}, \mathrm{~N}_{2}: 15$ mlbibit $^{-}$ ${ }^{1}, \mathrm{~N}_{3}: 22,5 \mathrm{ml} \mathrm{bibit}^{-1}, \mathrm{~N}_{4}: \quad 30 \mathrm{ml}$ bibit $^{-}$ 1. Masing-masing perlakuan diulang empat kali sehingga terdapat 20 polibag percobaan.

\section{Pelaksanaan Penelitian}

\section{Pembuatan Media Tanam}

Tanah yang digunakan dalam penelitian ini diambil dari kebun percobaan Fakultas Pertanian,Universitas Flores, Kelurahan Lokoboko, kecamatan Ndona, Kabupaten Ende. Tanah yang digunakan untuk media tanam dalam keadaan kering udara kemudian diayak dengan ayakan $2 \mathrm{~mm}$. Tanah yang sudah siap digunakan untuk media tanam selanjutnya dimasukkan ke dalam polibag yang berukuran tinggi $15 \mathrm{~cm}$ dan diameter $7,5 \mathrm{~cm}$ dengan perbandingan tanah : pasir : pupuk kompos (1:1:1).

\section{Persiapan Benih}

Benih yang berkulitas, dengan kriteria benih sebagai berikut:

1. Benih masak fisologis (warna kuning mudah sampai kehitaman)

2. Tidak cacat. 
Josina: Pengaruh pupuk organik cair Nasa terhadap pertumbuhan bibit tanaman Jati Putih (Gmelina arborea Roxb.)

3. Bebas dari hama dan penyakit.

Setelah selesai pemilihan benih, benih-benih tersebut direndam selama 24 jam, hal ini bertujuan untuk mengurangi kerasnya kulit pada biji jatih putih. Benih jati putih yang digunakan dalam bentuk biji yang sudah siap untuk ditanam.

\section{Persemaian}

Buah jati putih dipecahkan untuk diambil bijinya. Benih jati putih disemaikan terlebih dahulu dengan caradisebar merata pada bak-bak semai yang telah diisi media tanah, pasir, pupuk kompos (1:1:1). Setelah tujuh hari, benih yang telah berkecambah siap untuk dipindahkan ke dalam polibag. Pemindahan dilakukan secara hati-hati agar benih tidak mengalami kerusakan.

\section{Pemindahan Benih Ke Polibag}

Benih-benih yang ada pada bak-bak semai yang sudah tumbuh dengan baik, siap untuk dipindahkan. Pemindahan benih ke polibag dilakukan dengan hati- hati jangan sampai merusak perakaran dan bagian-bagian benih yang lain. Setelah benih dimasukan semua kedalam polibag, lalu dipindahkan ke rumah kaca.

\section{Aplikasi Pemupukan}

Untuk menambah pertumbuhan bibit serta meningkatkan kualitas tanah yang baik, maka perlu dilakukan pemupukan.Pemupukan dilakukan dengan mengunakan pupuk organik cair NASA dengan dosis yang diberikan sesuai dengan perlakuan $\mathrm{N}_{0}$ : tanpa pemberian pupuk atau $0 \mathrm{ml}$ bibi $^{-1}, \mathrm{~N}_{1}$ : $1,25 \mathrm{ml} \mathrm{bibit}^{-1}, \mathrm{~N}_{2}: 2,5 \mathrm{ml}$ bibit $^{-1}, \mathrm{~N}_{3}$ : 3,75 ml bibit ${ }^{-1}, \mathrm{~N}_{4}: 5 \mathrm{ml}$ bibit $^{-1}$. Pupuk organik cair NASA di berikan sebanyak 9 kali dengan interval waktu 10 hari sekali. Setiap kali pemberian dilarutkan dengan 1 liter air.

\section{Pemeliharaan Bibit}

Pemeliharaan bibit dilaksanakan mulai dari penanaman sampai dengan habisnya penelitian. Pemeliharaan bibit 
Josina: Pengaruh pupuk organik cair Nasa terhadap pertumbuhan bibit tanaman Jati Putih (Gmelina arborea Roxb.)

meliputi penyiraman, pengendalian gulma, pengendalian hama dan penyakit.

Penyiraman dilakukan sewaktu-waktu tergantung pada kondisi lapang dan kelembapan tanah.Jumlah air yang digunakan untuk setiap perlakuan adalah sama. Penyiangan terhadap gulma dengan cara mencabut gulma-gulma yang tumbuh,dan dilakukan secara rutin.

\section{Variabel Pengamatan}

Pengamatan pada benih, setelah 15 hari benih dimasukan ke dalam polibag, selanjutnya dilakukan pengukuran tiap 2 minggu hingga 6 kali pengukuran sehingga total umur tanaman yaitu \pm 90 hari. Adapun variabel yang diamati meliputi :

1. Tinggi tanaman $(\mathrm{cm})$

2. Jumlah daun $\tan ^{-1}$ (helai)

3. Luas daun $\tan ^{-1}\left(\mathrm{~cm}^{2}\right)$

4. Berat berangkasan segar $\tan ^{-1}(\mathrm{~g})$
5. Berat berangkasan kering oven $\tan ^{-1}$

(g)

\section{Analisis Data}

Data hasil pengamatan dianalisis dengan menggunakan analisis sidik ragam sesuai dengan rancangan acak kelompok (RAK). Apabila perlakuan menunjukkan pengaruh yang nyata atau sangat nyata terhadap variabel yang diamati, maka pengujian dilanjutkan dengan uji nilai beda rata-rata menggunakan uji BNT $5 \% \quad$ (Gomez dan Gomez, 1995).

\section{HASIL DAN PEMBAHASAN}

\section{Hasil}

Hasil analisis menunjukan bahwa pemberian dosis pupuk cair NASA yang berbeda berpengaruh sangat nyata terhadap tinggi tanaman, jumlah daun, luas daun, berat berangkas segar $\tan ^{-1}$ dan berat berangkas kering oven $\tan ^{-1}$ pada setiap pengamatan. 
Josina: Pengaruh pupuk organik cair Nasa terhadap pertumbuhan bibit tanaman Jati Putih (Gmelina arborea Roxb.)

Pembahasan

Veriabel Pertumbuhan

Hasil analisis sidik ragam

menunjukan bahwa pemberian dosis

Pupuk cair NASA yang berbeda

memberikan pengaruh yang nyata

terhadap veriabel jumlah daun, tinggi

tanaman dan luas daun pada setiap umur

pengamatan.

Pada perlakuan dosis $\mathrm{N}_{0}\left(0 \mathrm{ml} \mathrm{bibit}^{-1}\right)$

ke $\mathrm{N}_{1}\left(7,5 \mathrm{ml} \mathrm{bibit}^{-1}\right)$ terjadi peningkatan

rataan total tinggi tanaman, jumlah daun

dan luas daun sebesar $11,83 \%, 9,58 \%$ dan

$7,78 \%$, pada perlakuan dosis $\mathrm{N}_{0}(0 \mathrm{ml}$

bibit $\left.^{-1}\right) \quad$ ke $\quad \mathrm{N}_{2} \quad\left(15 \mathrm{ml}\right.$ bibit $\left.^{-1}\right)$ terjadi peningkatan rataan total tinggi tanaman, jumlah daun dan luas daun sebesar 15,86 $\%, 16,85 \%$ dan $43,27 \%$, pada perlakuan dosis $\mathrm{N}_{0}\left(0 \mathrm{ml} \mathrm{bibit}{ }^{-1}\right)$ ke $\mathrm{N}_{3}(22,5 \mathrm{ml}$ bibit $^{-1}$ ) terjadi peningkatan rataan total tinggi tanaman dan luas daun sebesar $20,13 \%, 21,14 \%$ dan $50,97 \%$ dan pada perlakuan dosis $\mathrm{N}_{0}\left(0 \mathrm{ml}\right.$ bibit $\left.^{-1}\right)$ ke $\mathrm{N}_{4}$ $\left(30 \mathrm{ml} \mathrm{bibit}^{-1}\right)$ terjadi peningkatan rataan total tinggi tanaman dan luas daun sebesar 23,65\%, 28,95\% dan 53,61\%, dengan demikian hipotesis yang pertama (1) terbukti. Hal ini karena pupuk organik cair NASA mengandung unsur hara dan zat pengatur tumbuh yang mengakibatkan bibit tanaman jati dapat tumbuh dengan baik. Selain itu, pupuk organik cair yang diberikan, dapat memperbaiki sifat fisik tanah (struktur tanah, porositas tanah dan permeabilitas tanah). Tanah yang telah membaik sifat fisik ini akan berlanjut pada meningkatnya kemampuan tanah untuk menyerap kation sebagai sumber hara makro dan hara mikro (Oktrianti, 2006).

Data yang tertera pada tabel 4.2 juga menunjukan bahwa hipotesis ke dua (2) ditolak. Hal ini terjadi karena pupuk organik cair NASA yang diberikan pada

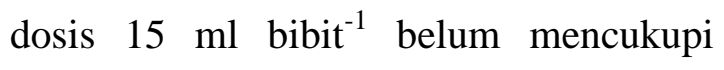
untuk pertumbuhan bibit tanaman jati 
Josina: Pengaruh pupuk organik cair Nasa terhadap pertumbuhan bibit tanaman Jati Putih (Gmelina arborea Roxb.)

sehingga tidak memberikan hasil yang optimal dibandingkan dengan pemberian pupuk NASA dengan dosis $30 \mathrm{ml} \mathrm{bibit}^{-1}$ yang memberikan pertumbuhan bibit tanaman jati putih yang optimal, hal ini karna pupuk NASA mengandung unsurunsur yang berguna bagi peningkatan pertumbuhan tanaman. Unsur-unsur tersebut adalah hara makro dan mikro yang berguna bagi pertumbuhan tanaman,selain itu, pupuk ini juga mengandung Zat pengatur tumbuh yang berguna bagi perkembangan organ-organ tanaman, sehingga penyerapan air dan hara menjadi lebih optimal (Anonimous, 2013). Kelebihan-kelebihan yang dimiliki oleh pupuk organik cair NASA inilah yang membuat semakin banyak dosis yang diberikan, semakin memberikan pengaruh yang optimal pada pertumbuhan bibit jati putih.

Bibit tanaman jati putih yang tidak diberi perlakuan dosis pupuk organik cair
NASA $\left(\mathrm{N}_{0}\right)$ memberikan kondisi penampilan tinggi tanaman, jumlah daun dan luas daun yang paling kecil jika dibandingkan dengan yang diberi perlakuan. Hal ini disebabkan karena kondisi tanah yang digunakan dalam percobaan iniadalah, $\mathrm{pH}$ agak masam (5,7), DHL rendah (1,58), C Oranik rendah $(1,73), \mathrm{N}$ total rendah $(0,15), \mathrm{P}$ tersedia Sedang $(17,25), \quad \mathrm{K}$ tersedia sedang (161,75), dan Tekstur tanah lempung berpasir (Tage, 2012). Kondisi tanah seperti ini belum dapat mendukung pertumbuhan bibit tanaman jati putih menjadi lebih baik. Jadi bibit tanaman jati putih yang tidak diberikan pupuk organik cair NASA memiliki pertumbuhan yang lebih rendah dari bibit tanaman yang diberikan perlakuan dosis pupuk organik cair NASA.

\section{Veriabel Berat Segar $\operatorname{Tan}^{-1}$ dan Berat Kerin Oven Tan ${ }^{-1}$}

Hasil analisis sidik ragam menunjukan bahwa pemberian dosis 
Josina: Pengaruh pupuk organik cair Nasa terhadap pertumbuhan bibit tanaman Jati Putih (Gmelina arborea Roxb.)

pupuk cair NASA yang berbeda memberikan pengaruh yan sangat nyata terhada veriabel berat segar $\tan ^{-1}$, berat kering oven $\tan ^{-1}$. Pada perlakuan dosis $\mathrm{N}_{0}\left(0 \mathrm{ml} \mathrm{bibit}{ }^{-1}\right)$ ke $\mathrm{N}_{1}\left(7,5 \mathrm{ml} \mathrm{bibit}^{-1}\right)$ terjadi peningkatan rataan total berat segar $\tan ^{-1}$, berat kerin oven $\tan ^{-1}$ sebesar $49,30 \%$ dan 40,32\%, pada perlakuan dosis $\mathrm{N}_{0}\left(0 \mathrm{ml}\right.$ bibit $\left.^{-1}\right)$ ke $\mathrm{N}_{2}\left(15 \mathrm{ml}\right.$ bibit $^{-}$

$\left.{ }^{1}\right)$ terjadi peningkatan rataan total berat segar $\tan ^{-1}$, berat kerin oven $\tan ^{-1}$ sebesar $54,05 \%$ dan $44,99 \%$, pada perlakuan dosis $\mathrm{N}_{0}\left(0 \mathrm{ml} \mathrm{bibit}{ }^{-1}\right)$ ke $\mathrm{N}_{3}(22,5 \mathrm{ml}$ bibit $^{-1}$ ) terjadi peningkatan rataan total berat segar $\tan ^{-1}$, berat kerin oven $\tan ^{-1}$ sebesar $56,66 \%$ dan $49,64 \%$, pada perlakuan dosis $\mathrm{N}_{0}\left(0 \mathrm{ml}\right.$ bibit $\left.^{-1}\right)$ ke $\mathrm{N}_{4}$ $\left(30 \mathrm{ml} \mathrm{bibit}^{-1}\right)$ terjadi peningkatan rataan total berat segar $\tan ^{-1}$, berat kerin oven $\tan ^{-1}$ sebesar 60,89\% dan 55,43\%. Data tersebut menunjukan bahwa hipotesis pertama diterima.
Hal ini dapat terjadi karena pupuk organik cair NASA memiliki kelebihan sebagai berikut: menjadikan tanah yang keras menjadi gembur secara berangsurangsur, melarutkan sisa pemakaian pupuk kimia dalam tanah (dapat dimanfaatkan oleh tanaman), memberikan semua jenis unsure hara, baik makro maupun mikro secara lengkap, dapat mengurangi penggunaan pupuk Urea dan SP-36 serta $\mathrm{KCl}$ sebanyak $12,5 \%-25 \%$, setiap 1 (satu) liter Pupuk Organik Cair Nasa mengandung fungsi unsur hara mikro yang setara dengan 1 ton pupuk kandang, memacu pertumbuhan tanaman serta akarnya, merangsang pengumbian, pembungaan dan pembuahan, juga dapat mengurangi kerontokan baik bunga maupun buah (mengandung hormon ZPT Auksin, Giberellin dan Sitokinin), membantu perkembangan mikroorganisme dan organisme dalam tanah yang berguna bagi tanaman seperti cacing 
Josina: Pengaruh pupuk organik cair Nasa terhadap pertumbuhan bibit tanaman Jati Putih (Gmelina arborea Roxb.)

tanah, Penicilium glaucum dan lainnya, dan meningkatkan daya tahan tanaman dari gangguan hama dan penyakit (Anonimous, 2013). Kelebihan-kelebihan dari pupuk organik cair NASA inilah yang mengakibatkan adanya peningkatan pada variabel pengamatan berat segar $\tan ^{-}$ ${ }^{1}$ dan berat kering oven $\tan ^{-1}$.

Perlakuan dosis cair NASA $30 \mathrm{ml}$ bibit $^{-1}\left(\mathrm{~N}_{4}\right)$ memberikan pengaruh pada variabel pengamatan berat segar $\tan ^{-1}$ dan berat kering oven $\tan ^{-1}$ bibit tanaman jati yang paling tinggi dibandingkan perlakuan lainnya. Hal ini dapat terjadi karena unsur-unsur yang terkandung di dalam pupuk organik cair NASA memiliki peran positif bagi peningkatan variabel pengamatan tersebut. Sehingga semakin banyak dosis yang diberikan, semakin memberi peningkatan pada ke dua variabel tersebut.

Berdasarkan data pada tabel 4.3 hal ini, maka hipotesis ke dua di tolak, karena kondisi tanah yang digunakan dalam percobaan ini adalah sebagai berikut, $\mathrm{pH}$ agak masam $(5,7)$, DHL rendah $(1,58), \mathrm{C}$ Organik rendah (1,73), $\mathrm{N}$ Total rendah $(0,15), \quad \mathrm{P}$ tersedia sedang $(17,25), \mathrm{K}$ Tersedia sedang $(161,75)$, dan Tekstur tanah lempung berpasir (Tage, 2012). Pupuk organik cair NASA mempunyai daya untuk meningkatkan kesuburan tanah, mempertinggi kadar humus, mendorong kehidupan jasad renik dan menambah unsur hara mikro yan dibutuhkan oleh tanaman agar tetap terjadi keseimbangan unsur hara dalam tanah (Anonimous, 2013). Sehingga, bibit tanaman yang tidak diberikan pupuk cair tersebut, memiliki pertumbuhan organ tanaman yang lebih rendah dibandingkan bibit yang diberikan dosis pupuk cair organik NASA.

\section{Kesimpulan}

1. Hasil penelitian menunjukan bahwa pemberian pupuk cair NASA dapat 
Josina: Pengaruh pupuk organik cair Nasa terhadap pertumbuhan bibit tanaman Jati Putih (Gmelina arborea Roxb.)

memberikan pengaruh yang sangat

nyata pada tinggi tanaman sebesar

23,65 \% dibandingkan denang

kontrol, jumlah daun sebesar 19,13\%

dibandingkan kontrol, luas daun

sebesar 53,61 \% dibandingkan

dengan kontrol, berat segar $\tan ^{-1}$

sebesar $60,89 \%$ dibandingkan

dengan kontrol, dan berat kering

oven $\tan ^{-1}$ sebesar $55,43 \%$

dibandingkan dengan kontrol.

2. Dosis optimum pupuk cair NASA yang memberikan pertumbuhan bibit tanaman jati putih adalah $30 \mathrm{ml} \mathrm{bibit}^{-}$ 1.

\section{Ucapan Terima Kasih}

Pada kesempatan ini penulis ingin mengucapkan terima kasih kepada semua pihak yang telah membantu dengan caranya masing-masing dalam melengkapi tulisan ini.

\section{DAFTAR PUSTAKA}

Adinugraha, A. H. 2010. Balai Besar Bioteknologi Penelitian dan Pemuliaan Tanaman Hutan.http://www.biotifor.or. id/modules/ publikasi /files /Aplikasi NASA-SNN pada bibit suren.pdf.Diakses pada tanggal 28 November 2013

Akbar, A., Agustinus P. Tampubolon., R. Ariyani dan F. Rijani. 1997. Penggunaan Pupuk Terhadap Pertumbuhsn Awal Gmeliana arborea roxb di Taharu Bukit Suharto, Kalimantan Timur. Buletin Teknologi Reboisasi. No. 1/1997. Hal 1 - 9.Banjar baru

Angkasa, Syah. 2000. Jati Ganjah Versus Jati Lokal. Trubus, Nomor 372

Andalusia, J. 2005. Penaruh Pupuk Kandang Sapi dan Pupuk N terhadap Pertumbuhan Bibit Jati Belanda. Proram studi aronomi Fakultas pertanian Instutii pertanian bogor:Bogor.

Anonimous. 2005. Potensi Tanaman Jati.http://library.usu.ac.id/down load/fp/hutan-edi batara10.pdf.di askes pada tanggal 9 Januari 2014.

Anonimous. $2009 . \quad J a t i$ Putih.http://id.wikipedia.org/wik i/Jati_putih. di akses pada tanggal 9 Januari 2014.

Anonimous. 2010.Pupuk Organik Cair NASA.http://www.produknatural nusantara.com/produknaturalnusantara/pupuk-organikcair-nasa.diakses pada tanggal 29 November 2013.

Anonimous, 2011. Tanaman Jati Putih.http://tipspetani.blogspot.c om/2011/04/tanaman-jati-putih- 
Josina: Pengaruh pupuk organik cair Nasa terhadap pertumbuhan bibit tanaman Jati Putih (Gmelina arborea Roxb.)

yang-semakin.html. diunggah 9 Januari 2014.

Anonimous. 2013. Pupuk Organik Cair

(POC) NASA.http://distributorresmi-

nasa.blogspot.com/2013/03/pupu

k-organik-cair-poc-nasa-

levelling.html.diakses pada

tanggal 29 November 2013.

Anonimous. 2013. Pupuk Nasa Dapat Menggantikan Fungsi Pupuk Kandang.http://www.supernasa.c om/2013/04/pupuk-nasamengganti-pupuk-kandang. html.diakses pada tanggal 29 November 2013.

Anonimous. 2013. Berinvestasi Tanaman Jati

Putih.http://sahabatppl.blogspot. com/2013/07/berinvestasidengan-tanam-jati-putih.html. diakses 9 Januari 2014.

Azhari. 2006. Pengaruh Kosentrasi Pupuk Organik Cair NASA Terhadap Pertumbuhan dan Hasil Tanaman Tomat. Program Studi Agroekoteknologi Fakultas Pertanian, Universitas Mura Bungo.

Dahlan, Mulyana dan Ceng, Asmarahman. 2010. 7 Jenis Kayu Penghasil Rupiah. Jakarta Agromedia Pustaka.

Gender,F.P. 1991. Fisiologis Tanaman Budidaya. Universitas Indonesia. Jakarta.

Gomez, K.A., Gomez, A.A. 1995. Prosedur Statistik untuk

Penelitian

Pertanian.(Syamsuddin, E., Baharsyah, J.S., Pentj)Jakarta. Universitas Indonesia.

Husna., Faisal., Mahfud. 2007. Aplikasi Mikoriza Untuk Memacu Pertumbuhan Jati Di
Muna.Jurnal Info Teknis Vol 5 no 1 juli.

Indrakusuma. 2000. Porposal Pupuk Organik Cair Supra Alam Lestari. PT Suriya Partama Alam. Jakarta.

Irwanto. 2006.Usaha Pengembangan Jati.(cited 2010 Novemer $14^{\text {th }}$ ) Available from : URL: http//www.irwantoshut.com

Kementrian Pertanian Direktorat Jandral Perkebunan. 2012. Statistik Perkebunan 2009-2011.

Lia. 2007. Pupuk Organik Cair. Penyebaran Semangat. Jakatra.

Novizan, I.R. 2002.Petunjuk Pemupukan Yang Efektif. Agro Media Pustaka: Tengerang.

Lingga. P. 2000. Petunjuk Penggunaan Pupuk. Swadaya, Jakarta.

Oktrianti. 2006. Penaruh Dosis Pupuk Organi Cair NASA Dan Macam Tanah Terhadap pertumbuhan Awal Mahkota Dewa. Fakultas Pertanian, Surakarta.

Pranantha A.A. 2014. Pengaruh Konsentrasi Larutan Pupuk Organik Cair (POC) Nasa Dan Komposisi Media Tanam Terhadap Pertumbuhan Semai Pinus (Pinus merkusii Jungh et de

vriese).http://www.researchgate. net/publication/50601961_penga ruh_konsentrasi_larutan_pupuk_ organik_cair_\%28poc\%29_nasa _dan_komposisi_media_tanam_t erhadap_pertumbuhan_semai_pi nus_\%28pinus_merkusii_jungh_ et_de_vriese $\% 29$.

Pratama, D. 2008. Penaruh Dosis Pupuk Cair Nasa Terhadap Pertumbuhan Bibit Tanaman Jati.

http://journal.muhamadiyah.ac.id 
Josina: Pengaruh pupuk organik cair Nasa terhadap pertumbuhan bibit tanaman Jati Putih (Gmelina arborea Roxb.)

/new/abstrak-pengaruh-dosisrootnef-pupuk-pupuk-cairNASA-terhadap-pertumbuhanbibit-jati.html. Diunduh tanggal 26 Fabruari 2013 jam 17.48.

Randi F., Rina Nirwan S., Iman Satyawibawa. Aribisnis Tanaman Perkebunan. Jakarta: Penebar Swadaya, 1994. Vi + 67p; ilus.;21p.

Rahmawati, H.,Iranto.,Hasan.2002, Informasi singkat benih Gmeliana Arborea. Dirokterat Pembenihan Tanaman Hutan.

Rinsema, W,T. 1986. Pupuk dan Cara Pemupukan. Bharata Kariya Aksara, Jakarta.

Saefudin, Sarief. 1980. Ilmu Tanah Pertanian (II). Fakultas Pertanian. UNPAD. Bandung.

Sitompul, S. M., Bambang, G. 1995. Analisis Pertumbuhan Tanaman. Yogyakarta: Gadja Mada University press.

Sitompul., Bambang uritno. 1995. Ilmu Tanah. Akademi Presindo. Jakarta.

Siregar, E. B. 2005. PotensiBudidayaJati.Medan: Fakultas Pertanian Program StudiKehutananUniversitas Sumatra Utara
Soetedjo, M.M. 2002. Pupuk dan Cara Pemupukan.Rhineka Cipta, Jakarta.

Sudiono Y. 1975. Tabel Tegakan 10 Jenis Kayu Industri. Bogor

Sugiharto,E.B.M. 2006. Pemanfaatan Pupuk Organik. Medan: JurnalTanamanHutan, (Online), Jilid 5, Nomor 7, (http://www.medan.ac.id), Diakses pada tanggal 17 April 2013.

Sukmadjaja, D,I., Mariska., K. Mlya. 2003. Perbanyakan Bibit Jati Melalui Kultur Jaringan. Balai Penelitian Bioteknologi dan Sumber Daya Genetik Pertanian. Bogor.

Suryana, Y. 2001. Budidaya Jati. BogorSwadaya.

Sutanto, Y. 2002. Kandungan Hara Makro Pupuk Organik. Penebar Swadaya. Bogor.

Tage, E. 2012. Pengaruh Mulsa Jerami Terhadap Pertumbuhan Dan Hasil Tanaman Cabai Merah. (Skripsi). Ende: Universitas Flores. 